\title{
THE WITHDRAWAL OF THE SOVIET/RUSSIAN ARMED FORCES AND THE END OF THE 1 OCCUPATION (ESSAY OF THE CHRONOLOGY OF THE TROOP WITHDRAWAL NEGOTIATIONS) ${ }^{1}$
}

\section{Vladimir Jarmolenko}

Former Ambassador of Lithuania to Bucharest, E-mail:

vladimir.jarmolenko@gmail.com

\begin{abstract}
Acknowledgements
This speech was presented at the Sixth international conference on Baltic and Nordic Studies in Romania Historical memory, the politics of memory and cultural identity: Romania, Scandinavia and the Baltic Sea Region in comparison, hosted by the Romanian Association for Baltic and Nordic Studies, Faculty of History and Political Sciences of Ovidius University of Constanța and International Summer School of The University of Oslo, Norway, May 22-23, 2015. Supported by a grant from Iceland, Lichtenstein and Norway, The EEA Fund for Bilateral Relations, contract no. 910/20.03.2015.
\end{abstract}

\begin{abstract}
:
This speech discusses the withdrawal of the Russian troops from the Republic of Lithuania mostly based on some personal recollections and the integration of research conclusions reached so far in the scholarly literature. The paper outlines the international environment which made the withdrawal of Russian troops from Lithuania possible, the goals of the Lithuanian side and the peaceful means to achieve them as well as the responsibility of foreign occupations resting upon the shoulders of Russian state then and now, as the legal heir of the Soviet Union. This speech is to be perceived as an exercise of historical memory.
\end{abstract}

\footnotetext{
${ }_{1}$ Mainly based on Ceslovas Stankevicius, Enhancing Security of Lithuania and Other Baltic States in 1992-94 and Future Guidelines http://www.nato.int/acad/fellow/9496/stankevi/home.htm (Č.V. Stankevičius, Derybos su Rusija dèl kariomenèe išvedimo iš Lietuvos (Vilnius: Leidybos centras KAM, 2002).
} 


\begin{abstract}
Rezumat:
Acest discurs discută retragerea trupelor rusești din Republica Lituania $\hat{\imath}$ mare parte pe baza unor amintiri personale și prin integrarea concluziilor cercetărilor realizate până $\hat{\imath}$ prezent în literatura de specialitate. Lucrarea descrie mediul internațional care a făcut posibilă retragerea trupelor rusești din Lituania, obiectivele lituaniene și mijloacele pașnice utilizate pentru a le atinge, precum și responsabilitatea ocupaț iei străine care cade în sarcina statului rus, atunci și acum, ca moș tenitor legal al Uniunii Sovietice. Acest discurs trebuie perceput ca un exercitiu de memorie istorică.
\end{abstract}

Keywords: Lithuania; foreign occupation; Russian troops; Soviet Union; Neostalinism, historical memory

Ladies, Gentlemen - Preparing myself for this Conference, I understood that it was necessary to offer the basic facts about what happened to Lithuania, why it had "to be born twice" in the bloody $20^{\text {th }}$ century.

Historical data reminds us of the current legal and political status of Lithuania. First of all, this year we celebrated the 25th anniversary of the restoration of Lithuania's independence. On March 11th, 1990 the Supreme Council (Parliament) of Lithuania declared the reestablishment of the sovereignty of the Republic of Lithuania. Lithuania embarked itself, on the road of peaceful parliamentary struggle, on a negotiated solution. Without real withdrawal of Soviet troops from the territory of independent and sovereign Lithuania the newly reborn State would have never been free. The restored state of Lithuania at that time needed to pursue three urgent priorities: the removal of Soviet/Russian troops, the joining to NATO, and membership of the EU.

Secondly, nowadays Russia's policy and Russian politicians express doubts whether Russia should take upon itself the "sins from the past". I think that allows me make a few observations concerning this issue.

What is more interesting, Russia, as the legal entity continuing the rights and obligations of the former USSR, tries to ignore the position expressed on December 24th, 1989 by the Congress of the People's Deputies of the USSR, following its decision on the political and legal evaluation of the Soviet-German Non-aggression Pact. Thereafter, the USSR recognized that the secret Soviet-German protocols (the Molotov- 
Ribbentrop Pact) and their accompanying acts had violated the sovereignty and independence of some third countries. The USSR itself therefore declared the Molotov-Ribbentrop Pact null and void from the very date of its signing. The Federal Republic of Germany declared the same on the 50 th anniversary of the outbreak of World War II.

Consequently, the leadership of the USSR, until the end of the existence of the USSR, resisted officially recognizing the re-established independence of Lithuania and avoided beginning genuine negotiations with it on the issue of the withdrawal of occupation troops.

Next day, on March 12th, 1990, the Parliament adopted a decree invalidating the military conscription law of the USSR for the citizens of the Republic of Lithuania. Appeal to the President of the Supreme Soviet of the USSR, Gorbachev, on March 13th, 1990, the Parliament appraised as illegal the stationing of Soviet troops on Lithuanian soil, and proposed negotiations regarding their withdrawal. By the decree of March 14th, 1990, the Parliament ceased the operation of the USSR military commissariat offices.

On August 7th, 1990, the Parliament approved the goals and provisions for negotiations with the USSR 2 .

Among them a goal was set to reach "an agreement on the terms and stages of the withdrawal of the USSR Armed Forces from the Republic of Lithuania". It was followed by same rounds of "talking" between officials, but on the USSR's side there was no real desire for negotiations.

In parallel, the state level negotiations continued with the Russian Federation, considering that on June 12th, 1990, there was a Declaration on the sovereignty of the Russian Federation.

On August 24th, 1990, in Vilnius a consultation between State delegations of the Republic of Lithuania and of the Russian Federation was held. The Head of the Lithuanian delegation was Ceslovas Stankevicius. This difficult process of bilateral consultations and meetings was successfully concluded after 10 mouths.

\footnotetext{
2 Decree of the Supreme Council of the Republic of Lithuania on the Basic Provisions and Objectives of Negotiations Between the Republic of Lithuania and the Union of Soviet Socialistic Republics - 7 August 1990; - Decree of the Supreme Council of the Republic of Lithuania on Parliamentary-Governmental Expert Groups Formed by the Committee on Political, Legal and Diplomatic preparations for Negotiations with the Union of Soviet Socialistic Republics - 7 August 1990.
} 
On July 29th, 1991, an official meeting of the state delegations of both countries under the leadership of the heads of the Republic of Lithuania and of the Russian Federation, Vytautas Landsbergis and Boris Yeltsin, took place in Moscow for the signing of the Treaty ${ }^{3}$. In Lithuania, the Treaty was ratified on August 19, 1991, before the day when the antidemocratic forces of the USSR attempted a coup d'etat in Moscow ${ }^{4}$.

On December 24th, 1991, the USSR formally ceased existing, and the Russian Federation declared itself the successor and assumed all rights, responsibilities and duties of the former Soviet Union.

Russian officials who declare that the occupation and annexation of Lithuania was legitimate are determined to forget that Russia supported an opposite position in the preamble of its July 29th, 1991 Treaty. In this document Russia declared that the USSR had to eliminate the consequences of the 1940 annexation which violated Lithuania's sovereignty. Thus, the opposite statements may be viewed as attempts to violate the fundamentals of the friendly relations between Russia and Lithuania.

On January 17th, $1992^{5}$ a Lithuanian-Russian Summit took place in Moscow. In a bilateral communiqué signed by Vytautas Landsbergis and Boris Yeltsin, the former USSR troops present on the territory of Lithuania were officially defined as "withdrawing forces under the jurisdiction of Russian Federation". It was agreed that these troops would be completely withdrawn and that this would be done in accordance with a special agreement. It was also agreed that, pending the completion of the withdrawal, these troops would not undertake any actions which might violate the sovereignty and laws of the Republic of Lithuania.

On January 31st, 1992, the first session of the State delegations for negotiations between the Republic of Lithuania (Head of the delegation Ceslovas Stankevicius) and of the Russian Federation (Head of the delegation Sergey Shakhray) took place in Vilnius. The bilateral communiqué fixed the agreed-upon date of February 1992 for the beginning

\footnotetext{
3 Treaty Between the Republic of Lithuania and the Russian Soviet Federated Socialist Republic on the Basis for Relations between States (signed in Moscow, on July 29, 1991).

4 The Russian Federation ratified this treaty half a year later - on January 17, 1992.

${ }^{5}$ On the same day, as the Russian Supreme Soviet ratified the Lithuanian-Russian Treaty.
} 
of the withdrawal of Russian troops from Lithuanian territory. It also stated that negotiations on the procedure for the withdrawal and the termination of the withdrawal would be held and that agreements would be made promptly.

On April 27th, 1992, the Parliament passed a bill to hold a referendum, which took place on June 14, 1992. Over 76 percent of Lithuania's citizens entitled to vote participated. 90 percent of those participating in the referendum expressed the demand that "the withdrawal of the former USSR troops from the territory of the Republic of Lithuania be commenced immediately and completed in 1992, and that the damage inflicted to the people of Lithuania and the state be compensated".

10 July 1992 - the CSCE Helsinki Summit final document called for the rapid withdrawal of Russian forces from the Baltic States in a simple manner: "withdrawal ... as soon, as possible". This formula was used in discussion on 19 July 1992 in the Petersberg Declaration (Bonn) on the meeting of WEU Council of Ministers. The Declaration stated that: “..6. Ministers recalled that the presence of foreign forces on the territory of a sovereign state requires the explicit consent of that state. They stressed the importance of rapidly establishing, in the negotiations under way, timetables for the withdrawal of foreign troops from the territory of the Baltic States".

On August 6th, 1992, Russia's Foreign Minister A. Kozyrev invited the Foreign Ministers of Baltic States to Moscow and raised the demand for the protection of the so-called Russian-speakers as a precondition for the withdrawal of the troops, saying that Russia would withdraw troops by 1994, if the following conditions were fulfilled:

1) laws concerning the rights of the Russian-speakers would be changed;

2) claims to border zone territories would be discarded;

3) the armed forces were given a legal status for their presence until their withdrawal;

4) strategic military possessions were preserved;

5) the demands for compensating the damage inflicted by the USSR during 1940-1991 were rescinded;

6) the Baltic States would undertake the construction of houses for the military of the units being withdrawn, in accord with the terms of the time-table for the withdrawal; 
7) Russia would be given guarantee of free military transit to Kaliningrad;

8) the real estate and other possessions left by the departing troops would be compensated to Russia;

9) social protection of the military and their families would be guaranteed;

10) the Baltic states would abstain from one-sided actions during the withdrawal period;

11) discrimination of the Russian legal and natural persons in the sphere of ownership and property relations would be abolished.

Lithuania assessed these demands as an ultimatum, as unjust, and without foundation, and therefore, unacceptable.

The negotiations which took place in an intense and harsh manner in Moscow ended early in the morning of September 8th, 1992. Foreign Affairs Minister Vitaliy Churkin also participated in them.

Seven agreements were prepared for signing. However, in the evening of September 8th, 1992, at the final meeting of the Heads of States and the delegations held in the Kremlin, Russia decided to sign only three of the agreements.

The following agreements were signed:

- on the time table for the withdrawal of the troops 6 ;

- on issues regarding the organizational and technical aspects for the withdrawal process7;

- regarding the procedure for functioning of the troops, pending their withdrawal ${ }^{\text {. }}$ (During the 9 months process of the preparation of negotiations the main goals were reached).

On 25 November 1992 - the United Nations General Assembly resolution called for the rapid withdrawal of Russian forces from the Baltic States.

\footnotetext{
6 Timetable for the Withdrawal of the Armed Forces of the Russian Federation from the Territory of the Republic of Lithuania (signed in Moscow on September 8, 1992).

7 Agreement between the Republic of Lithuania and the Russian Federation on the Rules of Behavior and Functioning of Units and Military Officers of the Withdrawing Armed Forces of the Russian Federation (signed in Moscow on September 8, 1992).

8 Protocol on the Procedure of Settlement of Technical and Organizational Questions on the Withdrawal of the Armed Forces of the Russian Federation from the Territory of the Republic of Lithuania (signed in Moscow on September 8, 1992).
} 
In 1993 the process of the real withdrawal was totally stopped. ${ }^{9}$ The Lithuanian position, especially the claim that Russian troops had been stationed in Lithuania illegally, and that Russia had to pay compensation for the damages inflicted by the troops since 1940, had drawn harsh criticism from Russia. On several occasions Russia accused Lithuania of purposefully delaying the signing of the agreement until the last troops were completely withdrawn from Lithuania on August 31st, 199310.

According to Professor Romain Yakemtchouk, it was "a fine victory for international law, which successfully passed a long 50 -year political and moral test"11

When on June 15th, 1940, the USSR invaded the Republic of Lithuania, the Soviet troops allocated for possible military actions against the Baltic States numbered 435,000 soldiers, around 8,000 guns and mortars, over 3,000 tanks, and over 500 armored cars.

The figures for the beginning of 1990 were as follows: Estonia - 200 000, Latvia - 30 000, Lithuania - 100000 troops. For the beginning of 1992: Estonia - 26 000, Latvia - 45-50 000, Lithuania - 45-50 000 troops. According the Russian official announcement at the UN General Assembly on 19 December 1994, "more than 100000 troops, 30000 families which comprise about 105000 people, 41.5 thousand pieces of equipment, about 700000 tons of military stockpiles were removed with 230 warships which left Lithuania, Latvia and Estonia", but in the document of the Assembly of WEU, "A European Defense policy", issued on 17 November, 1994, it was

\footnotetext{
9 See: http://www.nato.int/acad/fellow/94-96/stankevi/home.htm “In November, 1992, a general election to the Seimas took place in Lithuania and in February, 1993, a Presidential election was held. Both elections were won by former communists and Soviet nomenclature. Algirdas Brazauskas was elected as the President. Russia had a great interest in the results of these elections. While the new governance of Lithuania was being formed and the State delegation for negotiations was being changed (April 27, 1993), Russia waited. She did not make any secret of her hope that the new governance in Lithuania would make one-sided concessions to Russian demands."

10 On 31 August 1994 - Complete withdrawal of Russian troops from Estonia and Latvia, which coincided with the withdrawal of troops from other Central and Eastern European countries and from Eastern Germany.

11 R. Yakemtchouk, "Les republiques baltes en droit international: Echec d'une annexation operee en violation du droit des gens", The Baltic Path to Independence (New York, William S. Hein \& Co.: 1994), 261.
} 
indicated that "at the peak of its power, the Soviet Union had about 350000 troops stationed at over 1000 military bases in the three Baltic States"12.

Some points regarding the issue of the so-called Russian speakers and the retired Russian military officers:

Upon the withdrawal of its occupation forces from the Baltic States, Russia left behind not only a contaminated environment, but also a considerable number of retired military officers and other "colonizers". It is clear that there are Russian Lithuanians (they are citizens), but no Russians in Lithuania. In the Baltic States, the Russians and "colonizers" of other nationalities transferred here from "Great Russia" who stayed behind after the de-occupation are referred to by Russia as "Russian speakers". They are a political factor which Russia uses at an international level. To exert pressure on the Baltic States in order to isolate them, since 1992, Moscow has actively used the so-called problem of the rights of the Russian speakers (see: Andrei Kozyrev's points mentioned before).

It is clear that the presence of large Russian minorities (as population of the country) represents a cultural and political threat in that they might be used by Russia to justify future intervention in the domestic affairs of the Baltic States by Russia.

The main political paradigm of Russia now is very clear "... the defense of the ethnic Russian is not an aim, but a means"13. Russia presents the "... defense of the rights and interests of the Russian speakers" as a universal national interest in different countries in order to present them as an integral region ("immediate foreign space") where Russia bestows upon itself special rights ${ }^{14}$. There are opinions that the terminology "immediate foreign space" means not only territories of the former Russian empire, latter the former USSR, but also as the space for/of propaganda (or informational) war with useful instruments in Russian language (newspapers and magazines, TV and radio programs, and so on).

\footnotetext{
12 See document No. 1445, item 97, p. 13 of the Fortieth Ordinary Session of the Assembly of WEU.

13 The Main Provisions of the Military Doctrine of the Russian Federation. Approved for Decree No. 1833 of the President of the Russian Federation on November 2, 1993. Krasnaya zvezda, November 19, 1993.

14 J.B.K. Lough, "Defining Russia's Role in the Near Abroad" (Soviet Studies Research Centre, The Royal Military Academy, Sandhurst, April 1993).
} 
The processes in Russia today has a simple definition - "reestablishing of Neostalinism in Russia". Nothing has changed during the last 15 years in Europe, but something was changed dramatically in Putin's Russia.

The security environment in Europe is changing drastically. The ideas of revenge and military pressure on neighboring countries has totally been implanted in the "brains" of the Russian powerful elite and among the "population" of the state.

The results of this Russian policy can be seen to day in Moldova (from 1992), Georgia (from 1992 and the war of 2008), Crimea (from occupation of 2014) or in the Donbas region (from 2014).

Regarding the clarification of the terminology, it is necessary to clarify the slogans: "crisis and Russia" and/or "crisis with Russia".

Historically, the result of the vengeful and vindictive Russian policy will be the same: later or sooner - the collapse followed by the process of the withdrawal of Russian military troops from Ukraine and possible from others places in Europe.

\title{
RUSSIA?
}

The essential question of our modern times is - QUO VADIS,

As an answer, let me quote: - "Narod bezmolvstouet, the people are speechless" - which has become a Russian proverb. This is a final scene of "Boris Godunov" 15, by Alexander Pushkin:

\section{“... We have seen their dead bodies.}

(The People are silent with horror).

Why are you silent? Cry, Long live the tsar Dimitry Ivanovich!

(The people are speechless).

\author{
THE END “
}

This entire story is only an example of HISTORICAL MEMORY.

\footnotetext{
15 http://www.gutenberg.org/files/5089/5089-h/5089-h.htm - “Boris Godunov. A Drama in Verse", Alexander Pushkin, (translation: Alfred Hayes). 2004.
} 